\title{
THE “EQUI-BALANCING' FOREIGN POLICY OF THE PHILIPPINES TOWARD CHINA: THE IMPLEMENTATION OF THE PHILIPPINES' COOPERATIVE MARITIME DIPLOMACY TO CHINA IN THE SOUTH CHINA SEA DISPUTE
}

\author{
Jennie Joyce Candice, Anak Agung Banyu Perwita \\ School of International Relations \\ President University \\ E-mail: jenniefebrian@gmail.com \\ E-mail : aabanyu.perwita@gmail.com
}

\begin{abstract}
ABSTRAK
Artikel ini menjelaskan tentang implementasi kebijakan luar negeri "Equi-Balancing" Filipina terhadap China dalam sengketa Laut China Selatan (LCS). Artikel ini berpendapat bahwa untuk melindungi kepentingan nasional utamanya, Filipina harus dapat mengelola hubungan konstruktifnya dengan China. Untuk itu, Filipina di bawah pemerintahan Rodrigo Duterte merumuskan dan melaksanakan diplomasi maritim kooperatif terhadap China. Tujuan utama dari diplomasi maritim kooperatif ini adalah semakin mendekatkan hubungan Filipina-China dan di sisi lain, menjaga jarak diplomatik dengan Amerika Serikat dalam masalah Laut China Selatan. Artikel ini menggunakan metode kualitatif dalam menjelaskan implementasi diplomasi maritim kooperatif di atas. Untuk mencapai tujuan tersebut, Filipina telah melakukan beberapa tindakan konkrit dengan membangun: softpower, self confidence dan koalisi.

Kata kunci; Kepentingan nasional, perselisihan di Laut China Selatan, kebijakan luar negeri, diplomasi maritim kooperatif.

\section{ABSTRACT}

This article explicates the implementation of "Equi-Balancing" foreign policy of the Philippines toward China in the South China Sea (SCS) dispute. It argues that in order to protects its core national interests, Philippines should be able to manage its constructive relations with China. In order to do so, Philippines under the Rodrigo Duterte administration formulated and implemented cooperative maritime diplomacy to China. The main objectives of this cooperative maritime diplomacy were creating a closer the Philippines-China relations and on the hand, making some diplomatic distance to the United States in the SCS issue. This article utilises qualitative research method in deciphering the above cooperative maritime diplomacy. To achieve these goals, the Philippines has conducted several concrete actions by building: its sofpower, self confidence and coalition.
\end{abstract}

Keywords: National interests, South China Sea dispute, foreign policy, cooperative maritime diplomacy. 


\section{INTRODUCTION}

South China Sea (SCS) is one of the very critical trade routes for the international shipping lanes; it also becomes one of the important gateways for economic and strategic sub-region of Indo-pacific (Lowy Institute, 2020). Further, SCS is contained with the source of hydrocarbons specifically in natural gas with competing claims of the different ownership over the sea and the resources (EIA, 2019). Energy Information Administration (EIA) estimates that there are, at least, around 11 billion barrel of oil reserves and around 190 trillion cubic feet of natural gas reserves located in the SCS region(EIA, 2019).

The tensions and dispute in the SCS, particularly between China and the Philippines were started when China started to publish the Nine dash line maps in 2012. Nine-dash-line is a line that limited sea stretch from China's southern coast through the South China Sea(Fisher, 2016). For China, the sovereignty over four islands in SCS including Pratas Island, the Macclesfield Bank Island, Paracel Island and the Spratly Island are owned by for more than two centuries ago (CNN, 2016).

These territorial disputes between both countries have changed significantly in 2016 where there was a switching administration from former president Benigno Aquino to Rodrigo Duterte. Under Duterte administration, he decided to change the foreign policy of the Philippines to pursue the "Independent Foreign Policy". This foreign policy aims to maintain good relations with the major powers and not to take sides with any great powers. (DFA of the Philippines, 2016). Less than three months in the office and following the Permanent Court of Arbitration (PCA) landmark award to the Philippines in the territorial disputes with China in SCS, President Duterte released the diplomatic measures to get China's goodwill (Castro, Renato Cruz De, 2016). He reduces the tension in SCS in the ASEAN summit in Laos in an attempt to earn the diplomatic and economic concessions from China.

President Duterte stated that he wants to distance the Philippine's relations with the US and stopped joining the US navy to patrolling in SCS to avoid Beijing's upset (Castro, Renato Cruz De, 2016). Duterte also stated that he wanted American Special Forces that supported the Armed Forces of Philippines (AFP) operations in countering terrorism in Mindanao to withdraw from the island (Castro, Renato Cruz De, 2016). While he was distancing Philippines relations with the US, President Duterte has pursued the equibalancing policy which aims to closer the Philippines' relation with China. In order to win China's trust on the Philippines, President Duterte declared that the result of PCA on July 12 which won by the Philippines is purely a bilateral issue between both countries, not the matter for the ASEAN to echoing Chinese position in this matter(Oxford Daily Brief Service, 2016).

This article aims at responding the question on how Philippines responds China's assertive behavior in the South China Sea. More specicifically, this article deciphers how Philippines implement its cooperative maritime diplomacy to respond China behavior in the South China Sea. This article is divided into four sections. In the first section, it explains about the theory and concept that will be employed in this article. 
The second section discusses about the type of methodology that will be used in this article. In the third section, this article explicates the Philippines' cooperative maritime diplomacy implementation to manage the constructive bilateral relations with China in the SCS dispute to protect the Philippines' national interests. The Last section is the conclusion of this article.

\section{ANALYTICAL FRAMEWORK}

The main paradigm in this article is Neo-Realism. This paradigm is concerned about the structure of international and regional systems. Moreover, neorealism also explains how the countries have to show their capabilities to achieve their national interest.

Figure 1: Theoretical Framework Mind Map

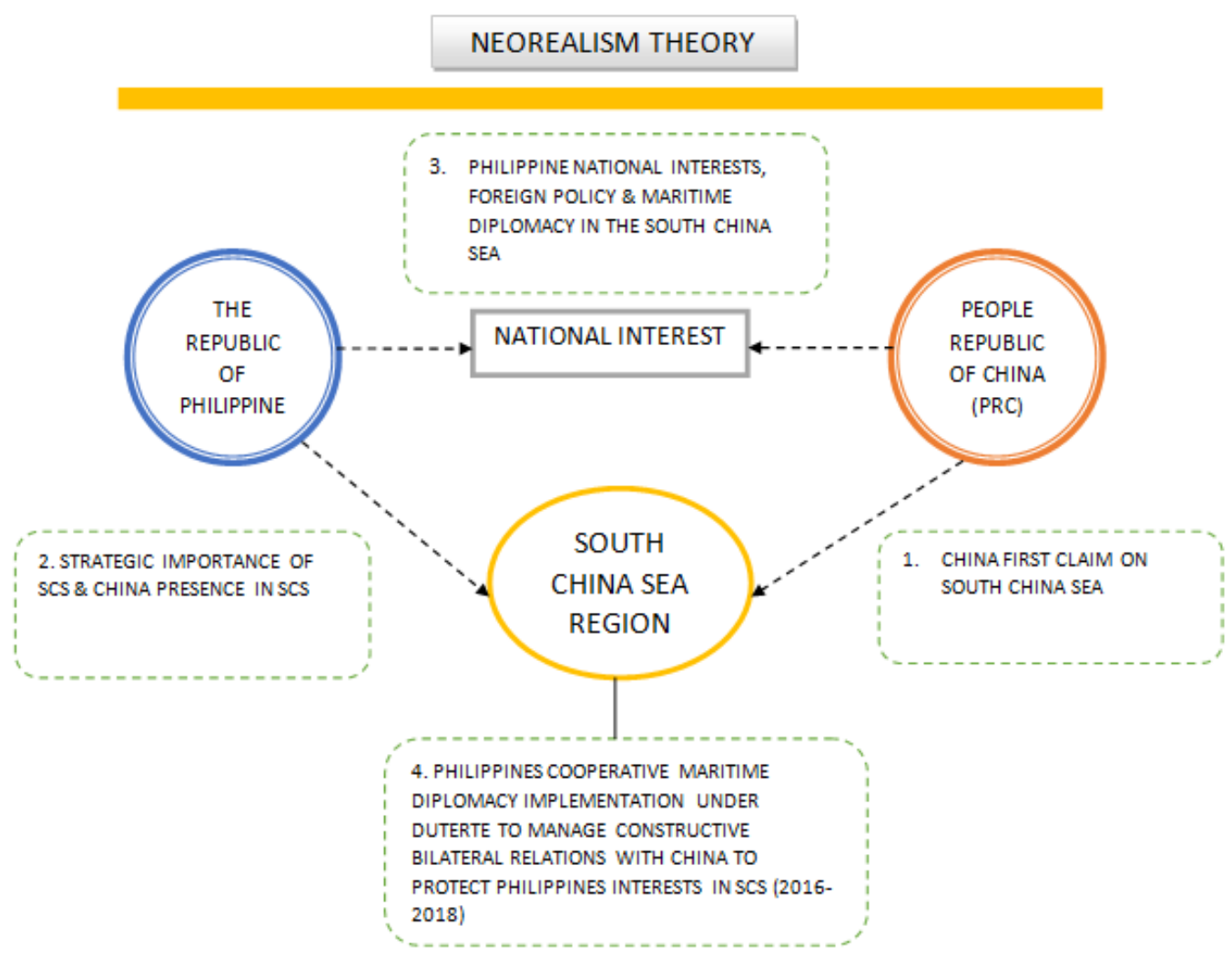

Generally, Neo-Realist argues that states are the highest level in the international system. According to Kenneth Waltz, the international system is known as a self-help system where the states are ready to satisfy the other countries in only specific conditions (Haetami, 2019). As Neo-Realist also argues that national interests of any nation-states are the most important driving force of their foreign policy behavior. In this context, a nation-state may reconcile the influences of international environment/system with its national interests. This would be applied with the case of Philippines' foreign policy toward China in the SCS. In one hand, Philippines seriously considered the influences of the international system as the essential 
external sources of its foreign policy, but on the other hand, Philippines has taken its national interests as the most pivotal source of its foreign policy in dealing with China.

The state policymaker will balance their own state conditions in order to attain and to earn their self-help system. The economic capabilities of a country will equally the same as the military power (Haetami, 2019). In the SCS dispute, Philippines' political interest is to protect Spartly Island and to pursue the bilateral relations with china. The security interest is to preserve the sovereignty and the integrity of national territory. The economy interest in South China Sea is to protect and manage the natural resources and the economic infrastructure in the SCS which will support Philippine's economic growth and development (EIA, 2019).

The other essential concept used in this article is maritime diplomacy. This concept can be understood as the way or strategy to maintain the relations through the maritime domain or the use of maritime to manage relations (LeMiere, 2016). In other words, maritime diplomacy is employed by a nationstate as an essential instrument in the foreign policy implementation in the maritime domain. As has been mentioned earlier, Philippines employs maritime diplomacy as the instument of its equi-balance foreign policy to respond China's behavior in the SCS. Conceptually, maritime diplomacy consists of three categorizations, namely: cooperative maritime diplomacy, persuasive maritime diplomacy and coercive maritime diplomacy(LeMiere, 2016). Cooperative maritime diplomacy is the using of soft power to manage the relations in the maritime domain; such as negotiations (LeMiere, 2016). Persuasive maritime diplomacy is the way of diplomacy that using the "influence", or to ask the target to follow what their interests is in the maritime domain. Persuasive maritime diplomacy is different from cooperative maritime diplomacy which is lack of collaboration or negotiation in managing maritime relations. While Coercive diplomacyor known as Gunboat diplomacy is the use or the implementation of diplomacy through hard power or naval capabilities in order to maintain their maritime relations (LeMiere, 2016).

In line with the above categorization of maritime diplomacy, this article discusses the Philippine's implementation of cooperative maritime diplomacy towards China in the South China Sea dispute (2016 2020). The cooperative maritime diplomacy that used by Philippine can be classified as an instrument in the implementation of Duterte's new 'equi-balancing' foreign policy which is also the part of independent foreign policy toward China in the SCS (Philippines Embassy, 2016).

\section{RESEARCH METHODOLOGY}

This article uses qualitative research method. Qualitative method is the type of scientific research to collect data from different study's perspectives. This research utlized primary and secondary data. For primary data, the writers use the official published reports from official government such as Philippines' embassy, Permanent Court of Arbitration Press Release Document 2016, as well as an official statement or 
document from the official websites of the government of the Philippines'. For the Secondary data, this article manages to use some books, journal articles written by the expert or scholars, and online websites pertinent to the case study.

\section{DISCUSSION}

\section{Rodrigo Duterte's "Equi-Balancing" Policy Strategy towards the Philippines' Relations with the} United States and China.

After Duterte came to power, he started to implement the equi balancing strategy towards the Philippines' relations with the major powers. The equi balancing strategy aims to pursue the closer relations with China in order to gain China's support on the economic aspects and to distance the Philippines relations with its allies, United States (Castro, Renato Cruz De, 2016). Not only distancing the Philippines' relations, but the Philippines' was also implementing the security separation with US and ended the joint military exercises in the South China Sea dispute.

Under Duterte's administration, he was planning to distance the Philippines' relations with the US. On September 13, 2016, Duterte's announced that he would end the joint patrol between both Philippines' and United States in the SCS, not only that, he also stated that the Philippines' navy have to limit the patrol in the country territorial waters in order to prevent the provocation from other neighborhood countries. During the ASEAN summit and the East Asian summit (EAS) in Laos, Duterte has given the critical speech to the former US president, Barrack Obama which caused the cancellation of the bilateral meeting between both leaders.

\section{The Termination of The Philippines' - US Joint Military Operations in Mindanao and Exercises in the South China Sea 2016}

Continuing from the cancellation of the bilateral meeting between Rodrigo Duterte and Barack Obama, on September 12 2016, Duterte announced that the US special forces that operating in the Mindanao for their counter terrorism operation had to leave the country, not only that Duterte's also blamed their presence could extended the conflict in the South China Sea(Aljazeera, 2016).

The US Special Forces was sent to the Southern Philippines' in order to help and provides the intelligence and the Philippines armed force to fight against the Abu Sayyaf terrorist groups which have linked to ISIS and Al Qaeda in the Southern Philippines'(Gomez, 2016). Duterte's also stated and warned that the Abu Sayyaf terrorism could kidnapping them if the American troops still staying there which might cause more complicated problems in Mindanao (Castro, Renato Cruz De, 2016). Later, Duterte stated that the Philippines' Navy would also stop joint patrol with the United States Navy in the Philippines' Exclusive 
Economic Zone (EEZ) which located in the South China Sea region in order to prevent China aggressive behavior.

Not only that, Perfecto Yasay, the Philippines' foreign secretary, also added that the Philippines' relations with the US regarding the joint patrol in the SCS can be seen as the provocative act by China which may cause the difficulties to peacefully solve the tension in the SCS between the Philippines' and China. In September 2017 during the Duterte's state visit to Vietnam, he has announced that the Joint military between the Philippines' and the US military exercises which started since 4-12 October 2016 were the last military exercises between both countries under his administration. Duterte also stated that he pledged to honor the longstanding defense treaty with the United States, besides that the statement which given by Duterte regarding the termination of the Philippines' and US joint military exercises was seen as a strongest indications of the slow breakdown towards the alliance that under Obama administration has tried to hold back the US rebalancing to the Asia(Castro, Renato Cruz De, 2016). During Duterte state visit to China in October 21, 2016, he announced the Philippines' separation from the US and Duterte has stated that the Philippines and China will ready to solve the SCS dispute through bilateral negotiations(Castro, Renato Cruz De, 2016).

\section{The Forms and The Goals of the Philippines' Cooperative Maritime Diplomacy}

The implementation of the Philippines' independent foreign policy under Duterte administration was started by the Philippines' effort to balance its relations with China in order to solve the tension in the South China Sea by creating the equi balancing policy which also the part of the independent foreign policy. In order to support the success of equi balancing policy, the Philippines has implemented the cooperative maritime diplomacy to China which can be seen in the table below. 
Figure 2: The Philippines's Maritime Diplomacy: The Forms and The Goals

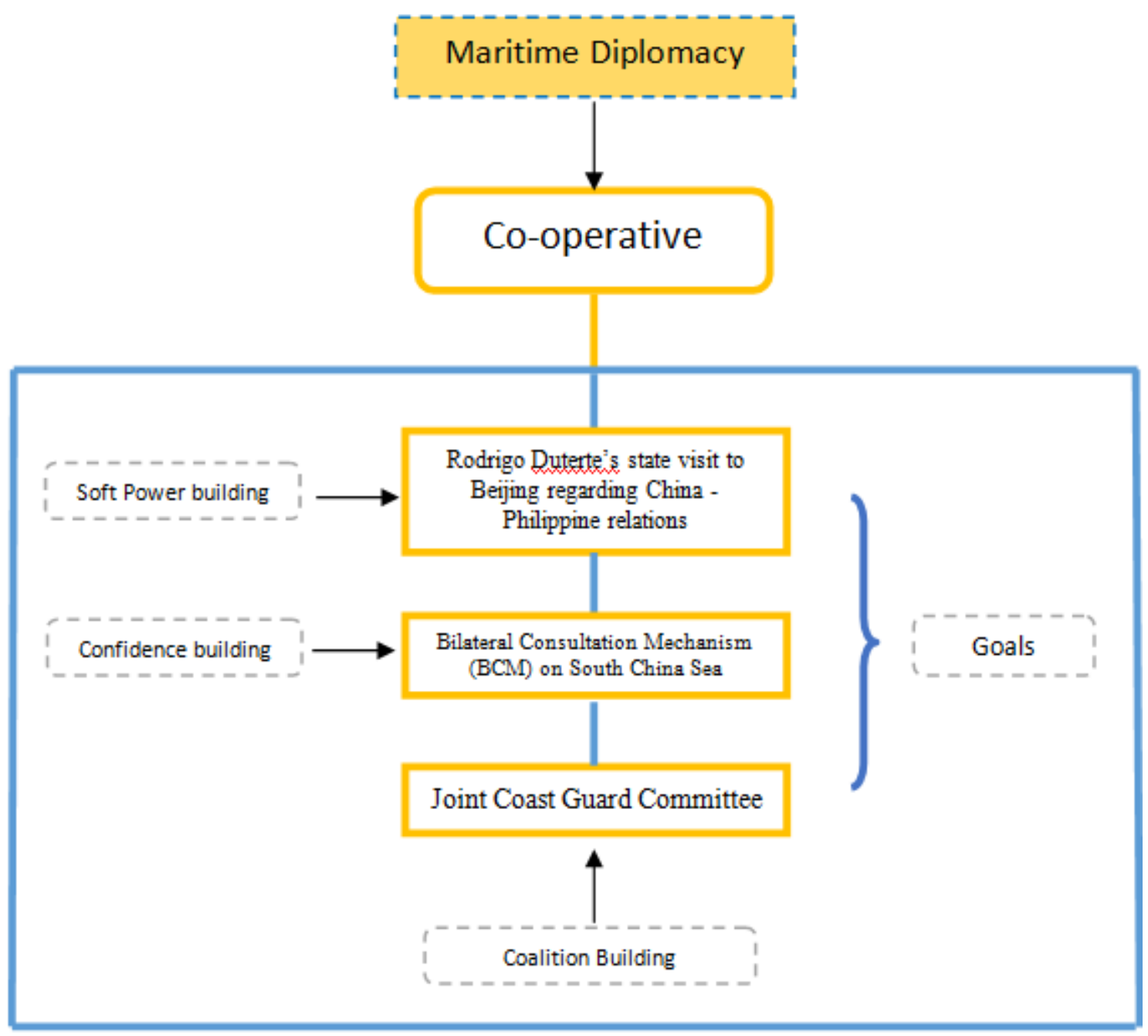

Source: compiled by the authors from various sources

The figure above explains about the Philippines' cooperative maritime diplomacy implementation in dealing with China in the South China Sea dispute. The nature of this cooperative maritime diplomacy can be classified into several actions. First, to conducts the state visit (very high-level state visits). Second is to conduct the Bilateral Consultation Mechanism (BCM) in the SCS, and third is to conducts the Joint Coast Guard Committee (JCGC) between China Coast Guard (CCG) and the Philippines' coast guard (PCG). There were three steps of cooperative maritime diplomacy that the Philippines' implemented to China: First is the soft power building, soft power building is used by the Philippines in order to earn China's trust by conducting the state visit to China to pursue more constructive bilateral relations between the two countries. Second is the confidence building. This step was taken to increase further mutual trusts and confidence between China and Philippines bilateral relations by implementing the Bilateral Consultation Mechanism (BCM) (The Departement of Foreign Affairs of the Philippines, 2019). BCM is one of the maritime diplomacy implementations in the form of confidence building to increase the mutual trust and confidence among both countries. 
By join the BCM with China, Philippines can manage the proper maritime incidents in the sea and increasing the maritime cooperation among both states in the SCS(The Departement of Foreign Affairs of the Philippines, 2019). With BCM, both countries can work together to maintain the regional peace and stability and to achieve the mutual goals and common interests in South China Sea. The BCM is one of the Philippine approaches to solve the maritime dispute with China and with BCM both countries have agreed to accelerate the negotiation without the use of force or hard power. In the other hand, Joint Coast Guard Committees (JCGC) is also the form of maritime diplomacy implementation in the maritime security aspects, by JCGC between both countries, it could protects and control the maritime areas in the South China Sea region from the transnational crimes and conducting environment protection(PCG, 2017).

The Last action is the coalition building. This action was implemented after the Philippines has succeeded to implement the soft power building and confidence building to China. This action serves as a strategy to achieve the Philippines' national interests by conducting the Joint Coast Guard Committee (JCGC) between China Coast Guard (CCG) and the Philippines Coast Guard (PCG) which officially signed during Duterte's state visit to China in 2016. The agreements were made to strengthen the bond between two allies in protecting the SCS region from the transnational and national crimes (LeMiere, 2016).

\section{The Economic Aspects of Philippines' Cooperative Maritime Diplomacy Implementation to China.}

Under Duterte's administration, he has emphasized more on the economic aspects. The economic policy was emphasized more on the macroeconomic stability, foreign investment and most importantly in the aspect of infrastructure development to promote the agricultural productivity and industrialization (Renato Cruz De Castro, 2018). As he believes that the fallen of the Philippines was caused by the poor infrastructure, he started to prioritize the development of the Philippines' infrastructure as it would create the employment and could reduce the inequality and poverty (Renato Cruz De Castro, 2018). Due to the huge Philippines' needs in economic aspects, Duterte has succeeded to create the independent foreign policy and equi balancing policy to attract more investment from China.

In 2016, Duterte visited China to renew their partnership. During the first meeting of both leaders, Xi Jinping endorsed Manila and Beijing to have to better coordinatation and working closer together in the One Belt One Road framework. After the meeting, Duterte and Xi Jinping agreed to have closer bilateral relations in economy such as in the construction of infrastructure (Renato Cruz De Castro, 2018). The equi balancing strategy is used to build the positive political atmosphere between China and Philippine bilateral relations where it builds the possibility of both countries to started to develop the infrastructure projects and main investment as the form of Cooperation that can create the trust and confidence building between China and Philippine in the SCS case(Castro, Renato Cruz De, 2016). 


\section{Rodrigo Duterte's State Visit to China Towards the Case of The South China Sea In 2016 The Philippines' - China Joint Statement Plan.}

Two years since Duterte's came to power, the relations between the Philippines and China have achieved more positive turnaround and a having a good momentum in the development (Jianwei, 2018). The implementation of his equi balancing policy can be seen when Duterte conducted the state visit to the China on October 2016. After that meeting, the Philippines and China were slowly able to strengthen the common trust-building(Renato Cruz De Castro, 2018).

To implement the soft power building to China and to earn China's trusts, Duterte made a three days state visit to China to discuss and build the economic relations between both countries. The matrix below is provided by the writers to summarize the Philippines' president, Rodrigo Duterte's state visit to China in 2016.

Figure 3: Duterte's State Visit in 2016 Matrix(The Philippines' Presidential Communications Operations Office, 2016)

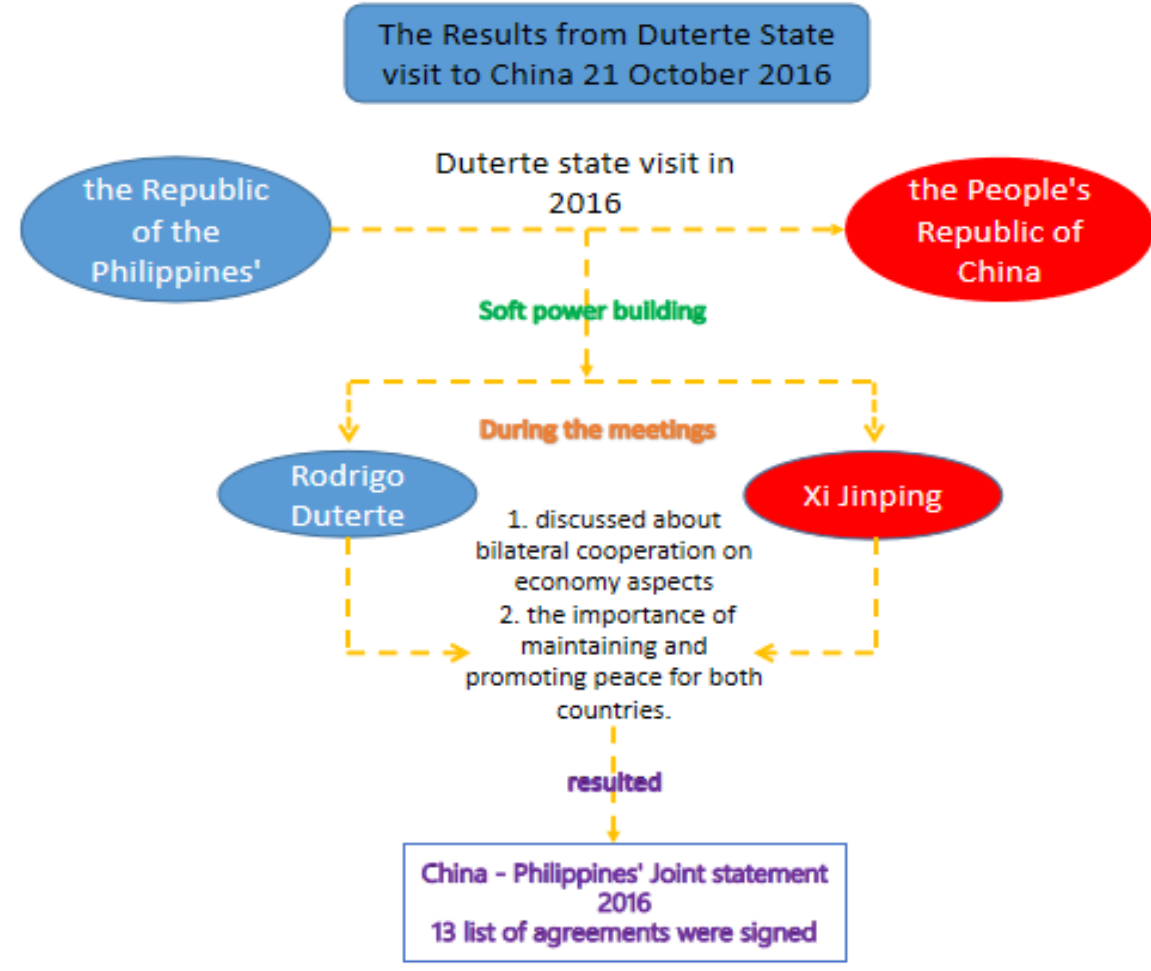

From the figure above we can see that, the two learders discussed about the economic bilateral relations of both countries (The Philippines' Presidential Communications Operations Office, 2016). Besides, they also discussed about the importance of maintaining and promoting peace in the SCS. There were 13 lists of documents signed and mostly on the economic aspects. Duterte also stated that the agreements would also provide the new framework to intensify both countries cooperation and also could upgrade the optimism in their trade relations (The Philippines' Presidential Communications Operations Office, 2016). 
Table 4: the Philippines' - China List of Signed Cooperation Documents 2016(Department of Foreign Affairs of the Philippines', 2016)

the Philippines' - China Joint Statements

13 List of Signed Cooperation Documents 2016

1. Agreement on Economic and Technical Cooperation between the Government of the Republic of the Philippines and the Government of the People's Republic of China

2. Memorandum of Understanding between the National Economic and Development Authority of the Republic of the Philippines and the National

Development and Reform Commission of the People's Republic of China for Developing Cooperation on Production Capacity and Investment

3.Memorandum of Understanding between the Department of Transportation and the Department of Public Works and Highways of the Republic of the Philippines and the National Development and Reform Commission of the People's Republic of China on Transportation Infrastructure Cooperation Project List

4.Memorandum of Understanding between the Department of Trade and Industry of the Republic of the Philippines and the Ministry of Commerce of the Government of the People's Republic of China on Strengthening Bilateral Trade, Investment and Economic Cooperation

5.Memorandum of Understanding between the National Economic and Development Authority of the Republic of the Philippines and the Ministry of Commerce of the People's Republic of China on Formulation of the Development Program for Economic Cooperation

6. Memorandum of Understanding between the Department of Finance of the Republic of the Philippines and the Ministry of Commerce of the People's Republic of China on Supporting the Conduct of Feasibility Studies for Major Projects

7. Action Plan on Agricultural Cooperation between the Department of Agriculture of the Republic of the Philippines and the Ministry of Agriculture of the People's Republic of China 2017-2019 the Philippines' - China Joint Statements

13 List of Signed Cooperation Documents 2016

8. Memorandum of Agreement between the State Council Information Office of the People's Republic of China and the Presidential Communications Operations Office of the Government of the Republic of the Philippines on News and Information Exchange, Training and for other Purposes

9. Memorandum of Understanding between the Department of Agriculture of the Republic of the Philippines and the General Administration of Quality Supervision Inspection and Quarantine of the

People's Republic of China on Cooperation of Animal and Plant Inspection and Quarantine

10. Memorandum of Understanding between the Philippine Coast Guard and the China Coast Guard on the Establishment of a Joint Coast Guard Committee on Maritime Cooperation

11. Implementation Program of the Memorandum of Understanding on Tourism Cooperation between the Department of Tourism of the Republic of the Philippines and the National Tourism Administration of the People's Republic of China 2017-2022

12. Protocol on Cooperation between the Philippines Drug Enforcement Agency and the Narcotics Control Bureau of the Ministry of Public Security of the People's Republic of China; and

13. Memorandum of Understanding on Financing Cooperation between the Export-Import Bank of China and the Government of the Republic of the Philippines, represented by the Department of Finance

From the two tables above (table 5), we can see that there were 13 lists of agreements mostly on economic aspects which signed in October 21, 2016. In the end of the joint statements, Duterte was also stated that he would provide the framework to intensify the cooperation of both countries relations (The Philippines' Presidential Communications Operations Office, 2016). Not only that, during Duterte's state visit to China, he also emphasized that his visit to China was a form of the turning point where both country can work together and showing their capability in the mutual cooperation that could bring advantage to both countries and keep maintaining the commitment to solve the South China Sea dispute in the peaceful way (The Philippines' Presidential Communications Operations Office, 2016).

Duterte conducted the second state visit to Beijing in order to participate in the "Belt and Road Forum for International Cooperation (BRF)" which was held by China on In May 13 to 15, 2017 along with other 29 world leaders (Embassy of the Philippines', 2020). Continued from the previous China and the Philippines' meeting discussion, Duterte was invited the China government in order to conduct the state visit in Manila. As a response to that invitation, China Prime Minister, Li Keqiang, conducted the state visit to Philippines' from 15-16 November 2017(Embassy of the Philippines', 2020). During the meetings, Li Keqiang and Duterte were having the view exchanged regarding China and the Philippines' relations as well 
discussed about the regional and international maritime issues. The meeting was resulted both countries were signed the 14 Government to Government Agreements and Memorandum of Understanding (MOU) (Embassy of the Philippines', 2020).

Figure 5: Duterte upgraded state visit in 2017 Matrix

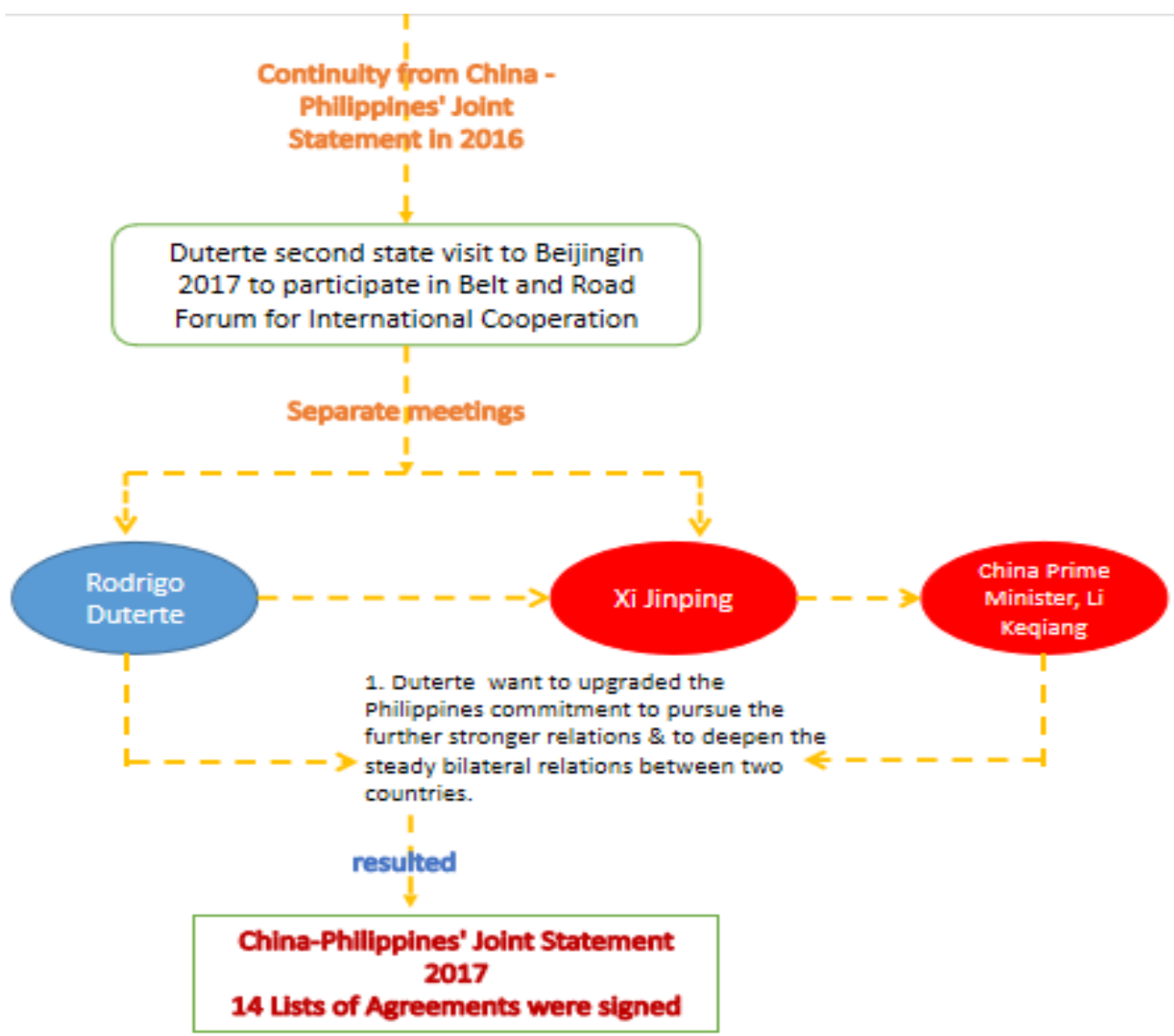

The tables below were the results from Duterte second times state visit to the China in 2017 to upgrade and expand further the China and Philippines' bilateral relations not only in economy, but also in socio-economic and security. 
Table 6: China and Philippines update joint statement 2017(Ministry of Foreign Affairs of the People's Republic of China, 2017)

China and the Philippines' joint statement 2017
14 list of Signed Cooperation Doctuments
1. Agreement on Economic and Technical Cooperation Between the
Government of the People's Republic of China and the Government of the
Republic of the Philippines.
2. Exchange Letter on Project of Dangerous Drugs Abuse Treatment and
Rehabilitation Centers Between the Government of the People's Republic of
China and the Government of the Republic of the Philippines.
3. Exchange Letter on Project of Two Bridges Across Pasig River Between the
Government of the People's Republic of China and the Government of the
Republic of the Philippines
4. Memorandum of Understanding For Cooperation on Industrial Parks
Development between the Ministry of Commerce of the People's Republic
of China and the Department of Trade and Industry of the Republic of the
Philippines.
5. Memorandum of Understanding on Jointly Promoting the Second Basket
of Key Infrastructure Projects Cooperation Between the Ministry of
Commerce of the the Government of the People's Republic of China and the
Department of Finance of the Government of the Republic of the Philippines.
6. Memorandum of Understanding on Jointly Promoting the Philippine
National Railways South Long Haul Project Cooperation between the
Ministry of Commerce of the People's Republic of China and the Department
of Transportation of the Republic of the Philippines.
7. Memorandum of Understanding between the National Development and
Reform Commission of the People's Republic of China and the Department
of Environment and Natural Resources of the Republic of the Philippines
Concerning the Provision of Goods for Addressing Climate Change.

China and the Philippines' joint statement 2017
8. Implementation Framework for the Memorandum of Understanding and
Development of Project List for Cooperation in Production Capacity and
Investment between The National Development and Reform Commission of
the People's Republic of China and The National Economic and Development
Authority of the Republic of the Philippines.
9. Memorandum of Understanding on Defense Industry Cooperation
between the State Administration of Science Technology Industry of National
Defense of the People's Republic of China and the Department of National
Defense of the Republic of the Philippines.
10. Memorandum of Understanding between the State Intellectual Property
Office of the People's Republic of China and the Intellectual Property Office
of the Republic of the Philippines on Cooperation in the field of Intellectual
Property.
11. Memorandum of Understanding between the All-China Youth Federation
and the National Youth Commission on Strengthening Youth Cooperation.
12. The Financing Cooperation Agreement on Chico River Pump Irrigation
Project and New Centennial Water Source-Kaliwa Dam Project between the
Export-Import Bank of China and the government of the Republic of the
Philippines represented by the Department of Finance.
13. Memorandum of Understanding between China Development Bank and
Bases Conversion and Development Authority.
14. The Republic of the Philippines 2017 Renminbi Bond Issuance
Underwriting Agreement.

\section{Philippine - China Joint Bilateral Consultation Mechanism (BCM) on SCS (2017-2019)}

As the continuity from Duterte's the state visit to China in October 2016, the Philippines' and China were agreed to conducts the Bilateral Consultation Mechanism (BCM) in the South China Sea which signed in 2016. The Bilateral Consultation Mechanism is a form of confidence building between China and the Philippines in order to earn the mutual confidence and trust. Besides, it also could control the aggressiveness of both countries to prevent the both countries to conduct the military activities in the South China Sea which will affects to the both countries peace and stability (Ministry of Foreign Affairs of the People's Republic of China, 2017).

The figure below is the summary and the results of both countries which agreed to conduct the Bilateral Consultation Mechanism (BCM) on South China Sea.

Figure 7: the Philippines'- China Bilateral Consultation Mechanism (BCM) Plan in South China Sea 
Results from Duterte's State

Visit to Beijing October 2016

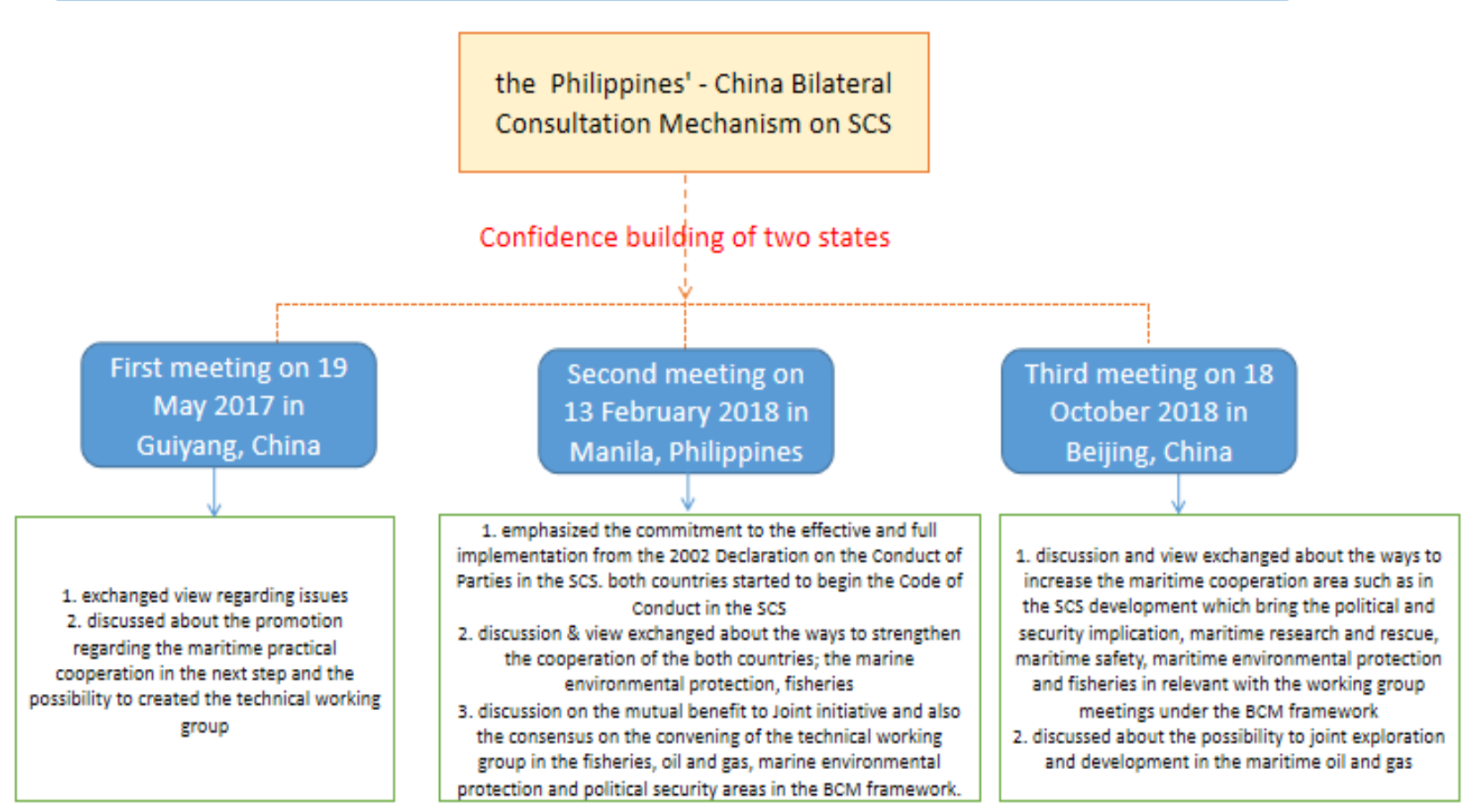

Source: compiled by the authors from various sources

As it can be seen from the table above, there were three meetings that held by the Philippines and China. During the first meeting, both countries have conducted view exchanged regarding the issue of South China Sea, and also discussed about the promotion regarding the maritime practical cooperation and the possibility for both sides to create the technical working group to solve the tension in SCS (Department of Foreign Affairs of the Philippines, 2017). While during the second meeting, they discussed and emphasized the commitment to the effective and full implementation of 2002 Declaration on the Code of Conduct Parties in the SCS. Not only that, both countries also having the discussion and view exchanged about the ways to strengthen the cooperation of both countries such as in marine environment protection and fisheries. Lastly, the meeting also discussed about the mutual benefits to joint initiative and the consensus on the convening of the technical working group in the fisheries, oil and gas, marine environmental protection and political security areas in the framework of BCM(Ministry of Foreign Affairs the People's Republic of China, 2018). During the third meeting, both sides discussed about the ways to increase the level and scope maritime cooperation areas in the SCS development that could bring the security and political advantages for both countries, such as: marine search and rescue, maritime safety, marine environment protection, and also fisheries which relevant to the working group meeting under the BCM framework. Both countries also discussed about the possibility to conduct joint explorations and development in the oil and gas sector (Ministry of Foreign Affairs of the Peoples Republic of China, 2018). 
During the first Bilateral Consultation Mechanism meeting on South China Sea which held in Guiyang, China on 19 May 2017, the meeting was represented by the Philippines ambassador to China, Jose Santiago L. Sta Romana and for the China representative was represented by Chinese Vise Minister of Foreign Affairs, Liu Zhenmin and also led the delegation to the Bilateral Consultation Mechanism. During the first meetings, both countries representative discussed and exchanged the view regarding the South China Sea issue in depth and friendly manner where both countries emphasized the assertiveness of their commitment to cooperate and looking for ways forwards in order to build the mutual trust and to build the confidence between China and Philippines (Department of Foreign Affairs of the Philippines, 2017).

According to the Joint Statement which was released on October 2016, both sides have agreed to move forward to discuss about the confidence building measures in order to increase the trust each other and to prevent both sides to conducting the activities in the South China Sea which could worsen both countries relations and could increase the tension in the South China Sea which also could impacted to the stability and also peace. In this case, the BCM is useful for both countries that would meet regularly and discuss on the current and further common issues in the SCS. Not only that, both countries China and the Philippines' have also agreed to explore and upgrade the cooperation in other areas (Department of Foreign Affairs of the Philippines, 2017). The head of the delegations also initiated on the Term of Reference which both countries have agreed to becomes the platform for "the confidence building measures and also promoting on the maritime cooperation and security".

In the second meeting of Bilateral Consultation Mechanism which held in the Manila, Philippines' on 13 February 2018. In this meeting, China representative and the delegation was led by the Vice Foreign Minister Kong Xuanyou, and the Philippines representatives was represented by the Undersecretary for Policy at the Department of Foreign Affairs, Enrique A. Manalo. During the meetings, both countries have emphasized more on their commitment to the effective and full implementation from " the 2002 Declaration on the Conduct of Parties in the SCS". Not only that, both countries were having the discussion and view exchanged about the ways to strengthen the cooperation of the both countries such as in the marine environmental protection, fisheries, marine scientific research and also on oil and gas without reducing both position on its sovereignty, sovereign rights, and the jurisdiction (Ministry of Foreign Affairs the People's Republic of China, 2018). There was also the intensive discussion on the mutual benefit to Joint initiative and also the consensus on the convening of the technical working group in the "fisheries, oil and gas, marine environmental protection, marine scientific research and political security areas" in the BCM framework. During the meeting, the working group has identified the possibility for both countries to do cooperative initiatives (Ministry of Foreign Affairs the People's Republic of China, 2018).

The third Bilateral Consultation Mechanism (BCM) meetings was held in Beijing, China on 18 October 2018. During the meeting, China delegations was led by Vice Foreign Minister Kong Xuanyou and while the Philippines' was represented by DFA Undersecretary for Policy, Enrique A. Manalo(Ministry of 
Foreign Affairs of the Peoples Republic of China, 2018). Having considered that the proper management in the SCS dispute was very important in maintaining the peace and the stability in regional, both sides have emphasized more on both commitment to the principles of "freedom of navigation in and over flight in the SCS region, the freedom of international commerce and also other peaceful use of the sea, handling the territorial dispute and jurisdiction in the peaceful way without using the hard power" (Ministry of Foreign Affairs of the Peoples Republic of China, 2018). Besides that, both countries also re-emphasized the important of commitment for the full and effective implementation of the "2002 Declaration on the Conduct of Parties in the SCS" $(D O C)$ in general and working together with the other ASEAN members which headed to the early consensus on the Code of Conduct in the SCS (COC). During the meetings, both countries were having the discussion and view exchanged about the ways to increase the maritime cooperation area such as in the SCS development which bring "the political and security implication, maritime research and rescue, maritime safety, maritime environmental protection and fisheries" in relevant with the working group meetings under the BCM framework(Ministry of Foreign Affairs of the Peoples Republic of China, 2018). Without reducing both countries portion on its sovereignty and sovereign rights and jurisdiction, both countries also discussed about the possibility to "joint exploration and development in the maritime oil and gas"(Ministry of Foreign Affairs of the Peoples Republic of China, 2018).

While, the fourth Bilateral Consultation Mechanism meeting was held on April 2-3, 2019 in Manila. The Chinese representative was led by the Vice Foreign Minister Kong Xuanyou and the Philippines' was represented by the Foreign Affairs Assistant, Secretary Meynardo LB. Montealegre from the office of Asian and Pacific Affairs (Xu Yi, 2019). In this meeting, both countries have emphasized that BCM is a forum that plays significant roles to create a steady development of bilateral relations. Both countries also emphasized the tensions in the SCS should not be ignored and the importance of maintaining and promoting regional peace and stability in the SCS are imperative not only for both countries but also for the region as a whole. Both sides were having view exchanges on ways to increase the maritime cooperation regarding the current development in the SCS that brings political and security implications, maritime search and rescue, marine environmental protection, marine safety and fishery in the Working Group meetings and under the BCM framework (FMPRC, 2019).

Both sides laso admitted the importance of the multilateral platform such as ASEAN-China Dialogue Relations, East and Asia Summit, and ASEAN Regional Forum in promoting peace and security in the SCS region. As closing statements, both sides reemphasized on their commitment on the full and effective implementation of the 2002 Declaration on the Conduct of Parties in the SCS and agreed to maintain the positive momentum of the negotiation towards the conclusion of a Code of Conducts in the SCS that based on the consensus (The Departement of Foreign Affairs of the Philippines, 2019).

The fifth meeting of the BCM on the SCS was held on October 28, 2019, in Beijing. The Philippines delegation was led by Foreign Affairs Undersecretary, Enrique A. Manalo and China delegation was led by 
Vice Foreign Minister, Luo Zhaohui (Department of Foreign Affairs of the Philippines, 2019). During the meetings, both sides were having view exchanges regarding the general issues of concern in the SCS and both countries maritime issues. Both sides admitted the needs to solve the SCS dispute and to review the progress on maritime cooperation in different fields. The working groups of the BCM on political security, Fisheries cooperation, marine environmental protection, and marine scientific research were formed. Both sides were also having further concerned issues which encompass the maritime search and rescue, marine research, marine safety and fisheries cooperation in the SCS (Department of Foreign Affairs of the Philippines, 2019).

\section{The Philippines - China Maritime Cooperation Joint Coast Guard Committees (JCGC) between Two Coast Guards in the South China Sea (2017-2019).}

The agreement of Joint Coast Guard between both countries was signed by Xi Jinping and Rodrigo Duterte, during Duterte's state visit in 2016. The two countries have agreed to have joint statement on the economic aspects as well as on the security aspect.

The implementation of the Joint committee between two coast guards in the SCS was started in 2016 where the Joint Coast Guard First Organizational Meeting of the the Philippines' Coast Guard (PCG) and China Coast Guard (CCG) was held on 15-16 December which located in Manila, Philippines. The Joint Coast Guard Committee (JCGC) was used as the venue for both coast guard to further strengthen the mutual trust, also as a form of coalition building and confidence building to build more intensive communications between both countries and increase the friendly cooperation in maritime domain (Dizon, 2016). During the first meeting, both countries were doing the view exchange regarding the establishment of the JCGC, including the principles of the organizational structure, Terms of Reference (TOR), and some operational procedure(Xinhua, 2016). Not only that, both sides have also discussed about the possibility to conduct the maritime cooperation programs such as: combating illegal trafficking, maritime crimes, marine environmental protection, maritime search and rescue and capacity building in related area(Xinhua, 2016). During the meeting both countries were also having the substantial discussions about the temporary settings for the proposed hotline communication, and both countries have agreed to hold the inaugural meeting and the second organizational meeting in February 2017 which would be held in the Philippines(Xinhua, 2016).

The Philippines' Coast Guard (PCG) and China Coast Guard (CCG) was hold the Inaugural meeting of Joint Coast Guard Committee (JCGC) and the Second Organizational Meeting on 20-22 February 2017 which were located in the Subic Bay, Philippines (Department of Foreign Affairs of the Philippines', 2017). The meeting was held in order to implement the MOU between the Philippines Coast Guard and China Coast Guard about the formation of the JCGC on the maritime cooperation which has been signed in 2016 between the two leaders, Xi Jinping and Rodrigo Duterte. During the inaugural meeting of the JCGC, the 
undersecretary of the Maritime sector of the Departement of Transportation, Hon Felipe. A. Judan delivered the speech about the Philippines' strong support on the Coast Guard Diplomacy which advocated by the PCG and CCG. He also stated that the "mutual understanding, friendship and cooperation" between both countries Coast Guard would have the important role in strengthening the Philippines and China bilateral relations (Department of Foreign Affairs of the Philippines', 2017).

In addition to that, both sides also emphasized the importance of Coast Guard diplomacy. The Joint Coast Guard has adopted the guideline implementation of the MOU and the Terms of Reference (TOR) of the Working Group which was created to help the work of the committee. Both countries have agreed to cooperate in "preventing and combating drug trafficking sectors and also other transnational crimes, search and rescue (SAR), environment protection, and emergency response, for examples, through the exchange information, modalities, and also unique pragmatic empowerment activities" for the enforcement agencies and the coast guards(the Philippines' Coast Guard, 2017). Both countries also created the hotline mechanism in order to facilitate the communication in the agreed areas. In order to enhance the cooperation between both countries law maritime enforcement agencies, in 2017, both countries agreed to conduct the bilateral exchanged activities which including the "maritime operation and exercise, capacity building and vesse/ visit" (the Philippines' Coast Guard, 2017).

During the second meeting of the JCGC in Guangzhou, China in October 9-11, 2018, both countries have agreed to further expand the cooperation by conducting the regular port visit, joint exercises, personnel exchange and training also the utilization of the hotline communication. Further, both countries also stated and emphasized their willingness to further elevate their bilateral relations and mutual trust to obtain their common objectves, such as the increasing of the quality of sea environment, a safer and more secure marine environment and promoting the coast guard diplomacy (the Philippines' Coast Guard, 2018). At the end of the meeting, both countries concluded that the Joint Coast Guard Committee was the important platform for Manila and Beijing to manage the issue and also to expand the level of collaboration between the two countries and to contribute more peaceful and stable environment in the region (the Philippines' Coast Guard, 2018).

As the continuity of the second meeting of JCGC in 2018, China Coast Guard (CCG) was conducting an official visit to the Philippines for the first time on January 14, 2020, . The CCG visit aims to strengthen the dialogue and cooperation on maritime law enforcement of both countries. During the visit, both sides agreed to conduct different activities such as cross deck visit, search and rescue and fire fighting exercise, and the sport games. The CCG visit was beneficial to deepen mutual trust and understanding of both countries and will enhance the cooperation (China Embassy, 2020). During the visit, both sides also agreed to conduct the third meeting of JCGC on January 14-16, 2020. During the third meeting of JCGC between CCG and the PCG were led by Major General Wang Zhongcai, Director General of CCG, and Vice Admiral Joel Sarsiban Gracia, the 28th Commandant of PCG. During the meetings, both sides were discussing about 
the next cooperation projects and new cooperation fields which aims to increase mutual trusts and to ensure the win-win outcomes in maritime cooperation. Besides, both sides have agreed to focus on the fishermen safety and protection. Both sides emphasized on their commitment to deepen the cooperation between CCG and PCG, jointly addressing maritime emergencies, to concern on the environmental and humanitarian protection, and to build the SCS into a sea of peace, stability and prosperity (Li Jiayao, 2020).

\section{Xi Jinping's State Visit to Philippines' in 2018 to 2020.}

Related with the Duterte state visit to China in 2016 and 2017 in pursuing more constructive bilateral relations Xi Jinping made the two-days state visit to Manila in November 2018 (Jianwei, 2018). During this state visit, the two leaders discussed about the expansion and the upgrade of economic and functional cooperation in several main areas, namely in investment promotion, bilateral trade, enhancing tourism and agriculture, education, science and technology, and cultural exchanged (Embassy of the Philippines', 2020).

On the aspect of SCS dispute, the two countries agreed to further increase the level of mutual trust as the basis for better bilateral relations. The two leaders produced the Joint Statement on the South China Sea. It has been explicitly stated that:

"Both sides agree to exercise self-restraint in the conduct of activities in the South China Sea that would complicate or escalate disputes and affect peace and stability. Both sides also note the importance of confidence-building measures to increase mutual trust and confidence. In this regard, both sides affirm the importance of the Bilateral Consultation Mechanism on the South China Sea and the Joint Coast Guard Committee on Maritime Cooperation"(XinHua, 2018).

In additio to that, both president Rodrigo Duterte and Xi Jinping also witnessed the signing of the new updates 29 Government to Government Agreements. The two tables below were the results of Xi Jinping state visit to the on November 21, 2018. 
Table 8: 29 Lists of Agreements and MOU between the Philippines and China Joint Statement

2018(XinHua, 2018)

29 List of Agreements and MOU between the People's Republic of China and the Republic of the Philippines 21 November 2018, Manila

1. Memorandum of Understanding between the Government of the People's Republic of China and the Government of the Republic of the Philippines on Cooperation within the Framework of the Belt and Road Initiative

2. MOU on Cooperation on Oil and Gas Development between the Government of the People's Republic of China and the Government of the Republic of the Philippines

3.Agreement on Economic and Technical Cooperation between the Government of the People's Republic of China and the Government of the Republic of the Philippines

4..Infrastructure Cooperation Program between the Government of the People's Republic China and the Government of the Republic of the Philippines

5.Program for Cooperation on Industrial Parks Development between the Government of the People's Republic of China and the Government of the Republic of the Philippines

11.Memorandum of Understanding on Basic Education between the Ministry of Education of the People's Republic of China and the Department of Education of the Republic of the Philippines

12.Memorandum of Understanding on Promoting Cooperation in Information and Communications Industry Between the Ministry of Industry and Information Technology of the People's Republic of China and the Department of Information and Communications Technology of the Republic of the Philippines
6.The Exchange Letter on the Implementation of the Davao River Bridge Project between the Government of the People's Republic of China and the Government of the Republic of the Philippines

7.The Exchange Letter on the Implementation of the Road and Bridge Project in Marawi between the Government of the People's Republic of China and the Government of the Republic of the Philippines

8. Exchange of Letters on Project of Container Inspection Equipment between the Government of the People's Republic of China and the Government of the Republic of the Philippines

9.. Handover Certificate of Emergency Humanitarian Cash Assistance between the Government of the People's Republic of China and the Government of the Republic of the Philippines

10. Executive Program of the Cultural Agreement between the Government of the People's Republic of China and the Republic of the Philippines for 2019-2023

13.Memorandum of Understanding between the Ministry of Agriculture and Rural Affairs of the People's Republic of China and the Cooperative Development Authority Office of the Republic of the Philippines on Strengthening the Building of Agricultural Cooperatives

14. Memorandum of Understanding on Jointly Promoting Cooperation in Key Infrastructure Projects in Davao Region between the Ministry of Commerce of the Government of the People's Republic of China and the Department of Finance of the Government of the Republic of the Philippines

Table 9: 29 Lists of Agreements and MOU between the Philippines and China Joint Statement 2018(XinHua, 2018).

29 List of Agreements and MOU between the People's Republic of China and the Republic of the Philippines 21 November 2018, Manila

15.Implementation Agreement of the Feasibility Study of Panay-Guimaras- 23.Memorandum of Understanding on Panda Bonds Issuance Negros Island Bridge

16.Implementation Agreement of the Feasibility Study of Davao City Expressway Project

17.Memorandum of Understanding on Renminbi Clearing Arrangement

18.Protocol of Phytosanitary Requirements for Export of Fresh Young Coconuts from the Philippines to China between the General Administration of Customs of the People's Republic of China and the Department of Agriculture of the Republic of the Philippines

19.Protocol of Sanitary and Phytosanitary Requirements for Export of Frozen Fruits from the Philippines to China between the General Administration of Customs of the People's Republic of China and the Department of Agriculture of the Republic of the Philippines

20.Memorandum of Understanding on Supporting the Feasibility Study of Major Projects between the China International Development Cooperation Agency of the Government of the People's Republic of China and the Department of Finance of the Government of the Republic of the Philippines

21.Memorandum of Understanding between China Foreign Affairs University of the People's Republic of China and the Foreign Service Institute of the Republic of the Philippines

22.Preferential Buyer's Credit Loan Agreement on the New Centennia Water Source-Kaliwa Dam Project between the Export-Import Bank of China and the Metropolitan Waterworks and Sewage System (MWSS)
24.Commercial Contract of Safe Philippines Project, Phase I

25. Contract Agreement of the New Centennial Water Source-Kaliwa Dam Project between China Engineering Corporation and the Metropolitan Waterworks and Sewage System (MWSS)

26. MOA for the Development of a China-Philippines Mixed Use Industrial Park in the New Clark City

27.Project Management Consultancy Contract of the Philippine Nationa Railway South Long Haul Project between the China Railway Design Corporation and the Department of Transportation of the Republic of the Philippines

28. Letter of No Objection to the Organization of the Renminbi-Philippine Peso Foreign Exchange Trading Market

29..Certificate of Authority to Operate for the Industrial and Commercia Bank of China (ICBC) Limited-Manila Branch 
As can be seen in the two tables above (table 8 and table 9), there were 29 list of agreements which have been signed by both countries. During the joint press conference, Xi Jinping has emphasized that China and the Philippines' are having common interests and the two countries would keep continue to work together to manage the contentious issue and also promote the friendly maritime cooperation through bilateral consultation in the SCS(Jianwei, 2018).

As the continuity of China-Philippines Joint Statement on November 2018, Rodrigo Duterte was conducting the state visit to Beijing upon Xi Jinping invitation to attend the 2019 International Basketball Federation, Basketball World Cup which was held in Beijing.

During the meeting, both presidents discussed about the human rights and the SCS issue, on the human rights discussion, Xi Jinping stated that he would always support the Philippines national sovereignty and to resist on external interference (FMPRC, 2019). Xi Jinping also stated that China and the Philippines were committed to maintaining the effective communication in managing the SCS dispute in a proper way (FMPRC, 2019). During the meeting, both countries also restated that the Code of Conduct in the SCS is a pioneering effort to set the rules and regulation in the SCS in which China and the Philippines had to commit more to promote the adoption of the COC to maintain the long term stability in the SCS region (FMPRC, 2019).

As started from 2020 the Corona Virus is starting to expand in China, both countries didn't conduct any meeting until September 2020. In September 11, 2020, China's State Councilor and Defense Minister Wei Fenghe was visiting Manila in to discuss about the SCS dispute (CGTN News, 2020). During the meeting, Duterte was expressing his gratitude for Chinese government and military for supporting the Philippines by giving the assistance to fight against the COVID-19. Duterte stated that the state visit during the pandemic have shown the importance to maintain the bilateral relations between both countries. During the meeting, Chinese State Councilor and Defense Minister stated that both countries should strengthen the communication and the coordination to properly manage any differences in the SCS dispute (CGTN News, 2020).

Both sides were agreed to manage the peace and stability in the SCS region in order to achieve the common interests of all countries. During the meeting, Duterte stated that he hoped both countries could continue to solve the SCS tensions and differences through negotiations and in respect with the international law. As a response, Defense Minister Wei Fenghe emphasized that it was both countries responsibility to maintain the peace and stability in the SCS region (CGTN News, 2020). 


\section{CONCLUSION.}

The main task of any nation-states in their foreign relations is to make sure the attainment of their national interests. It is even more than necessary to any nation-states to do everything they can with everything they have to promote their national interests in the dispute and conflict situation. This article has shown the efforts of the Philippines under Rodrigo Duterte administration in protecting its national interest's vis a vis China in the South China Sea dipute.

In order to advancing its national interests as well as to keep its constructive bilateral relations with China, Rodrigo Duterte has adopted an independent and "equi-balancing" foreign policy toward China. As has been explicated, this foreign policy aims at aims pursuing a closer relation with China in order to gain China's support on the economic aspects of the Philippines national development and politically, creating a distance of the Philippines relations with its main ally, United States.

The main instrument of the "equi-balancing' policy of Duterte's is by exercising a cooperative maritime diplomacy to China which can be categorized into three aspects. The first is the soft power building. This action was conducted by the Philippines in order to earn China's trust by conducting the state visit to China in order to maintan the constructive bilateral relations with China. The second action is confidence building by implementing the Bilateral Consultation Mechanism (BCM) between Philippines' and China in the South China Sea. The last step is the coalition building with China by conducting the Joint Coast Guard Committee (JCGC) between China Coast Guard (CCG) and the Philippines Coast Guard (PCG). These agreements were made to strengthen the bond between the two countries in protecting the SCS region from the non-traditional security threats, namely: the transnational and national crimes.

Considering the ongoing dispute in the SCS, it is very imperative for all the claimants to advance non-violence behaviors in mitigating any possible open conflicts in the waterways. The use of cooperative maritime diplomacy by all the claimant states in the SCS can be concluded as the most essential diplomatic instrument in managing the relations among the claimant states. In this context, Philippines has successfully implemented its cooperative maritime diplomacy in managing both its bilateral relations with China and promoting a more constructive regional stability in the SCS. 


\section{REFERENCES}

Aljazeera. (2016, September 13). Duterte to US forces: Get out of southern Philippines. Retrieved August 18, 2020, from https://www.aljazeera.com/news/2016/09/duterte-forces-southern-philippines160913003704576.html

AMTI. (2016, June 30). GEOPOLITICAL CONSTRAINTS ON DUTERTE'S SOUTH CHINA SEA POLICY. Retrieved August 3, 2020, from Asia Maritime Transparency Initiative: https://amti.csis.org/geopolitical-constraints-dutertes-south-china-sea-policy/

AMTI. (2016, October 19). PRESIDENT DUTERTE MAINTAINS PHILIPPINE-JAPANESE PARTNERSHIP AS HE "PIVOTS" TO CHINA. Retrieved August 3, 2020, from Asian Maritime Transparency Initative: https://amti.csis.org/president-duterte-maintains-philippine-japanese-partnership-pivots-china/

BBC. (2016, October 20). Duterte in China: Xi lauds 'milestone' Duterte visit. Retrieved August 19, 2020, from BBC: https://www.bbc.com/news/world-asia-37700409

Blanchard, B. (2016, October 20). Duterte aligns Philippines with China, says U.S. has lost. Retrieved August 19, 2020, from UK Reuters: https://uk.reuters.com/article/uk-china-philippines-idUKKCN12K13D

Castro, Renato Cruz De. (2016). The Duterte Administration's Foreign Policy: Unravelling the Aquino Administration's Balancing Agenda on an Emergent China. Journal of Current Southeast Asian Affairs, 140.

Chen, D. (2014, December 2). Xi Jinping's Evolution of Chinese Grand Strategy. Retrieved June 30, 2020, from The Diplomat: https://thediplomat.com/2014/12/xi-jinpings-evolution-of-chinese-grandstrategy/

CNN. (2016, August 2). Showdown in the South China Sea: How did we get here? Retrieved June 30, 2020, from CNN: https://edition.cnn.com/2015/10/28/asia/china-south-china-sea-disputesexplainer/index.html

Cohen, S. B. (2014). Geopolitics: The Geography of International Relations.

D Clinton, Thompson \& Morgenthau. (1948). Politics Among Nations (7th ed.).

Department of Foreign Affairs of the Philippines'. (2017, February 28). INAUGURAL MEETING OF THE JOINT COAST GUARD COMMITTEE: PHILIPPINES AND CHINESE COAST GUARDS AGREE TO FURTHER ADVANCE COOPERATION. Retrieved August 22, 2020, from https://www.dfa.gov.ph/dfareleases/11832-inaugural-meeting-of-the-joint-coast-guard-committee-philippines-and-chinesecoast-guards-agree-to-further-advance-cooperation

Department of Foreign Affairs of the Philippines. (2017, May 19). Joint Press Release for the First meeting of the Philippines - China Bilateral Consultation Mechanism on the South China Sea. Retrieved August 20, 2020, from Department of Foreign Affairs of the Philippines: https://dfa.gov.ph/newsroom/dfa-releasesupdate/12694-joint-press-release-for-the-first-meetingof-the-philippines-china-bilateral-consultation-mechanism-on-the-south-china-sea

Department of Foreign Affairs of the Philippines'. (2016, October 21). Joint Statement of the Republic of the Philippines and the People's Republic of China. Retrieved August 19, 2020, from https://dfa.gov.ph/newsroom/dfa-releases/10748-joint-statement-of-the-republic-of-thephilippines-and-the-people-s-republic-of-china 
DFA of the Philippines. (2016). Philippine Foreign Policy. Retrieved June 12, 2020, from Embassy of the Philippines: https://romepe.dfa.gov.ph/the-embassy/philippine-foreignpolicy\#: :text=Article\%20II\%2C\%20Section\%207\%3A\%20\%E2\%80\%9C,Republic\%20Act\%20No.

Dizon, J. (2016, December 16). Retrieved August 22, 2020, from Update Philippines': https://www.update.ph/2016/12/ph-china-hold-first-meeting-to-organize-joint-coast-guardcommittee/12243

EIA. (2019, October 15). South China Sea Region. Retrieved June 11, 2020, from US Energy Information Administration : https://www.eia.gov/international/analysis/regions-of-interest/South_China_Sea

Embassy of the Philippines'. (2020, July 1). Philippines - China relations. Retrieved August 19, 2020, from Embassy of the Philippines - Beijing, China: https://beijingpe.dfa.gov.ph/list-of-bilateralagreements/84-phl-chn-relations

FHI.org. (n.d.). Qualitative Research Methods Overview. Qualitative Research Methods: A Data Collector's Field Guide, 2-3.

Fisher, M. (2016, July 14). The South China Sea: Explaining the Dispute. Retrieved 2020, from NewYork Times: https://www.nytimes.com/2016/07/15/world/asia/south-china-sea-dispute-arbitrationexplained.html

Gomez, J. (2016, September 12). Philippine president wants U.S. troops out of country's restive south. Retrieved August 18, 2020, from TheStar: https://www.thestar.com/news/world/2016/09/12/philippine-president-wants-us-troops-out-ofcountrys-restive-south.html

Haetami. (2019). CHINA COERCIVE DIPLOMACY THROUGH SOUTH CHINA SEA. Defense Departement, 48.

Javad Heydarian. (2011, October 4). Manila's Balancing Act. Retrieved August 2, 2020, from The Diplomat: https://thediplomat.com/2011/10/manilas-balancing-act/

Jianwei, L. (2018, December). Xi's Visit to the Philippines: Implications for China-Philippine Relations. Retrieved August 19, 2020, from Insitute for Security \& Development Policy: https://www.isdp.eu/publication/xis-visit-to-the-philippines/

Kuhn, R. (2013, June 4). Xi Jinping's Chinese Dream. Retrieved June 5, 2020, from NewYork Times: http://www.nytimes.com/2013/06/05/opinion/global/xi-jinpings-chinesedream.html?pagewanted $=$ all\&_r $=0$

LeMiere, C. (2016). Maritime diplomacy in 21st century. Naval policy and history , 7-14.

Lowy Institute. (2020). Lowy Institute. Retrieved June 4, 2020, from South China Sea Overview: https://www.lowyinstitute.org/issues/south-china-sea

ManilaTimes. (2019, July 21). Duterte's independent foreign policy is a pro-Philippine policy. Retrieved August 8, 2020, from https://www.manilatimes.net/2019/07/21/opinion/analysis/dutertesindependent-foreign-policy-is-a-pro-philippine-policy/587349/

Ministry of Foreign Affairs of the People's Republic of China. (2017, November 16). Joint Statement between the Government of the People's Republic of China and the Government of the Republic of the Philippines. Retrieved August 20, 2020, from Ministry of Foreign Affairs of the People's Republic of China: https://www.fmprc.gov.cn/mfa_eng/wjdt_665385/2649_665393/t1511299.shtml 
Ministry of Foreign Affairs of the Peoples Republic of China. (2018, October 18). THIRD MEETING OF THE CHINA-PHILIPPINES BILATERAL CONSULTATION MECHANISM ON THE SOUTH CHINA SEA(BCM). Retrieved August 21, 2020, from https://www.fmprc.gov.cn/mfa_eng/wjbxw/t1605180.shtml

Ministry of Foreign Affairs the People's Republic of China. (2018, February 13). The Second Meeting of China-Philippines Bilateral Consultation Mechanism on the South China Sea Held in Manila. Retrieved August 21, 2020, from https://www.fmprc.gov.cn/mfa_eng/wjbxw/t1536593.shtml

Oxford Daily Brief Service. (2016). Philippines: New Foreign Policy may be Destabilizing,. Oxford Analytica, 1.

PCA. (2016, July 12). The South China Sea Arbitration: The Philippines vs The PRC. Retrieved June 10, 2020, from PCA Press Release: https://docs.pca-cpa.org/2016/07/PH-CN-20160712-Press-Release-No-11English.pdf

PCG. (2017, February 22). INAUGURAL MEETING OF THE JOINT COAST GUARD COMMITTEE: PHILIPPINE AND CHINA COAST GUARD AGREE TO FURTHER ADVANCE COOPERATION. Retrieved August 3, 2020, from Philippine Coast Guard: http://www.coastguard.gov.ph/index.php/11-news/1484inaugural-meeting-of-the-joint-coast-guard-committee-philippine-and-china-coast-guard-agreeto-further-advance-cooperation

People's Daily. (2016, October 10). Xi-Duterte Agree on Full Improvement of Ties,. Retrieved June 13, 2020, from Global Security: http://www.globalsecurity.org/military/library/news/2016/10/mil-161020pdo01.m=3n.002a.1849.hs0ao4c71.1p7j

Philippines Embassy. (2016). Philippine Foreign Policy. Retrieved June 12, 2020, from Embassy of the Philippines: https://romepe.dfa.gov.ph/the-embassy/philippine-foreignpolicy\#: :text=Article\%20II\%2C\%20Section\%207\%3A\%20\%E2\%80\%9C,Republic\%20Act\%20No.

Rabena, A. J. (2018, June 29). Understanding the Philippines'South China Sea Policy. Retrieved August 4, 2020, from Maritime Executive: https://www.maritime-executive.com/editorials/understanding-thephilippines-south-china-sea-policy

Renato Cruz De Castro. (2018). How Indo-Pacific Geopolitics Affects Foreign Policy: The Case of the Philippines, 2010-2017. 133-155.

Stake. (2010). Qualitative Research Studying How Things Work. 23.

The Departement of Foreign Affairs of the Philippines. (2019, April 3). PHILIPPINES, CHINA CONVENE THE FOURTH MEETING OF THE BILATERAL CONSULTATION MECHANISM ON THE SOUTH CHINA SEA. Retrieved August 3, 2020, from https://www.dfa.gov.ph/dfa-news/dfa-releasesupdate/21081philippines-china-convene-the-fourth-meeting-of-the-bilateral-consultation-mechanism-on-thesouth-china-sea

the Philippines' Coast Guard. (2018, October 16). 2nd Joint Coast Guard Committee Meeting held in China. Retrieved August 22, 2020, from http://www.coastguard.gov.ph/index.php/11-news/24882nd-joint-coast-guard-committee-meeting-held-in-china-4

the Philippines' Coast Guard. (2017, February 22). INAUGURAL MEETING OF THE JOINT COAST GUARD COMMITTEE: PHILIPPINE AND CHINA COAST GUARD AGREE TO FURTHER ADVANCE COOPERATION. Retrieved August 22, 2020, from http://www.coastguard.gov.ph/index.php/11news/1484-inaugural-meeting-of-the-joint-coast-guard-committee-philippine-and-china-coastguard-agree-to-further-advance-cooperation 
The Philippines' Presidential Communications Operations Office. (2016, October 22). President Duterte's State Visits to China and Brunei enhance trade ties, 22 Oct. 2016. Retrieved August 19, 2020, from https://pcoo.gov.ph/president-dutertes-state-visits-to-china-and-brunei-enhance-trade-ties-22oct-2016/

Tweed, S. \&. (2014, December 2). Xi Jinping outline: Big Country Diplomacy For China. Retrieved June 4, 2020, from Sydney Morning Herald: http://www.smh.com.au/world/xi-jinping-outlinesbig-countrydiplomacy-for-china-20141202-11yaj5.html

Williams, P. D. (2008). Security Studies: An Introduction. New York: Routledge.

Xinhua. (2016, December 16). Coast guards of Philippines, China vow to enhance cooperation. Retrieved August 22, 2020, from http://en.people.cn/n3/2016/1216/c90000-9156031.html

XinHua. (2018, November 21). Joint Statement between the People's Republic of China and the Republic of the Philippines. Retrieved August 23, 2020, from http://www.xinhuanet.com/english/201811/21/c_137622271.htm

Zhaokui, F. (2014, October 21). What Are China's Core Interest? Retrieved June 30, 2020, from China-US Focus: https://www.chinausfocus.com/foreign-policy/what-are-chinas-core-interests-2 
Jurnal Studi Diplomasi dan Keamanan, Volume 13, No. 1, Januari 2021 